- But the agreement - to be called the Cartagena Protocol, after the Colombian city where an earlier round of negotiations ended inconclusively last year - does not claim precedence over the rules of the World Trade

Organization (WTO), and exporters who believe they are being treated unfairly will still have recourse to the WTO.

The Biosafety Protocol is the first treaty based on the Convention on Biological Diversity, established at the Rio Earth Summit in 1992. The United States - the largest exporter of GM food - has not ratified the convention, but it played a leading role in the Montreal negotiations and says that it will abide by the protocol.

Although the protocol was conceived chiefly to control the introduction of living organisms into foreign ecosystems, discussions soon became embroiled in arguments about bulk movements of grain. In Cartagena, the United States and some of its foodexporting allies sought to exclude grain shipments from the protocol, arguing that they posed no environmental or health risk, and that a protocol that included commodities would be used to bar imports of US grain.

But observers say that US and European negotiators at Montreal were under pressure to obtain an agreement after the failure of last November's WTO talks in Seattle. Agricultural biotechnology companies, who had encouraged the US to oppose a protocol covering commodities, were prepared to accept the relatively mild controls on commodity shipments: these will not come into force until two years after the protocol is ratified by 50 countries. Colin Macilwain

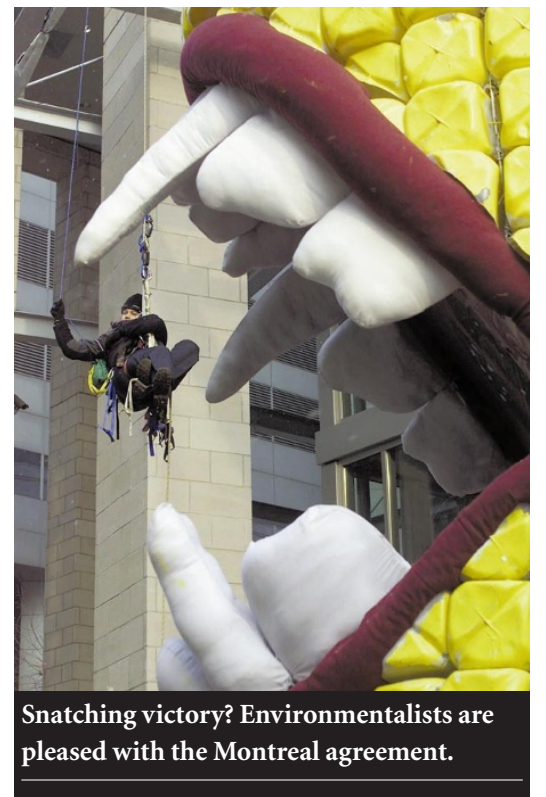

\title{
German science begins to cure its historical amnesia
}

\section{Berlin}

Documents relating to the Nazi era from the files of Adolf Butenhandt, director of the Kaiser Wilhelm Institute for Biochemistry in Berlin during that time, and later head of the Max Planck Society (MPS), will this week be opened for the first time for examination by historians of science.

The decision to open up the archives reflects a new determination by top MPS officials to come to terms with the wartime activities of scientists who worked for its predecessor, the Kaiser Wilhelm Society (KWS). Butenhandt, who won the Nobel prize for chemistry in 1939 for his work on the isolation of sex hormones and went on to develop the one gene-one enzyme hypothesis, is widely revered as a hero of postwar German science.

Although the KWS lost many of its scientific élite during the Third Reich, when Jews and other 'undesirables' were expelled, the MPS has only recently started to address the role of those remaining scientists in supporting Nazi policy. Many continued their careers in the MPS and in universities after the war, and effectively blocked enquiries into their activities and those of their colleagues during the Third Reich. Investigations became taboo.

The taboo is now ending. The MPS has contracted a group of researchers to examine the role of KWS scientists in developing and supporting Nazi policies, and Butenandt's files, which were to have remained closed in the MPS archives for 30 years after his death in 1995, are being made available to them.

But tensions remain. Last week, Robert Proctor, a historian of science from Pennsylvania State University who is working as a guest scientist with the German historians, was refused access to the archives on the grounds that the files had not been properly indexed. However, after intervention from senior MPS officials, Proctor has been assured of access this week.

The MPS's actions contrast with its defensive stance during the 1980s when concerns were raised that, as head of the Berlin institute during the Second World War, Butenandt knew about - and therefore passively colluded with - research on human subjects that members of the KWS were carrying out.

Proctor, whose books include the recently published The Nazi War on Cancer (Princeton University Press, 1999), says that historical reflection can only help to normalize perspectives, and he applauds the action

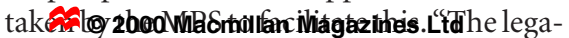
cy of Nazism influences the negative attitude many Germans show towards genetics today, and is probably responsible for the absence of a prominent science-orientated intellectual élite: where are the Goulds, Hawkings and Dawkins of Germany?" he asks.

\section{Turning a blind eye}

One outspoken critic of the veil of silence that he claims the postwar scientific community drew over the Nazi period is Benno Müller-Hill, a professor of genetics at the University of Cologne. He argues that "it is hard to imagine that a talented science administrator like Butenandt" could not have known, for example, that his colleague Günther Hillmann had analysed blood samples at his Institute for Biochemistry for an experiment at the Auschwitz concentration camp.

Müller-Hill had found evidence that Otmar Freiherr von Verschuer, director of the Kaiser Wilhelm Institute for Anthropology, Human Genetics and Eugenics in Berlin after 1942, worked with Josef Mengele on experiments to identify the hereditary aspects of resistance to infectious diseases.

The experiments involved infecting twins - mostly Jewish — with typhus or tuberculosis and observing the resulting pathologies. Blood samples were sent for analysis to Hillmann, who studied the 'defence enzymes' now known not to exist, but thought at the time to confer resistance to disease (see Nature 393, 109-111; 1998).

Müller-Hill was threatened with lawsuits by Butenandt and some of his influential former pupils before he published details of the Hillmann connection in his 1984 book Tödliche Wissenschaft (Murderous Science). But the lawsuits did not materialize. And Hubert Markl, the current MPS president, has acted to ensure that the society examines its past systematically, partly in response to pressure from the society's new generation of science historians.

In particular, the MPS is supporting a five-year research programme, 'The Kaiser Wilhelm Society during National Socialism', being carried out by seven external historians of science, and by visiting scientists. The group, headed by Doris Kaufmann, a professor of history at the Technical University of Berlin, started its work last year.

"The MPS had certainly been reluctant to dig into the details of its 'dark time'", says Kaufmann. She points out, for example, that only 50 pages in a 1,000-page 'Festschrift' commemorating 75 years of the KWS/MPS relates to the period 1933-45. "It's embarrassing."

Kaufmann insists that "we don't want to 

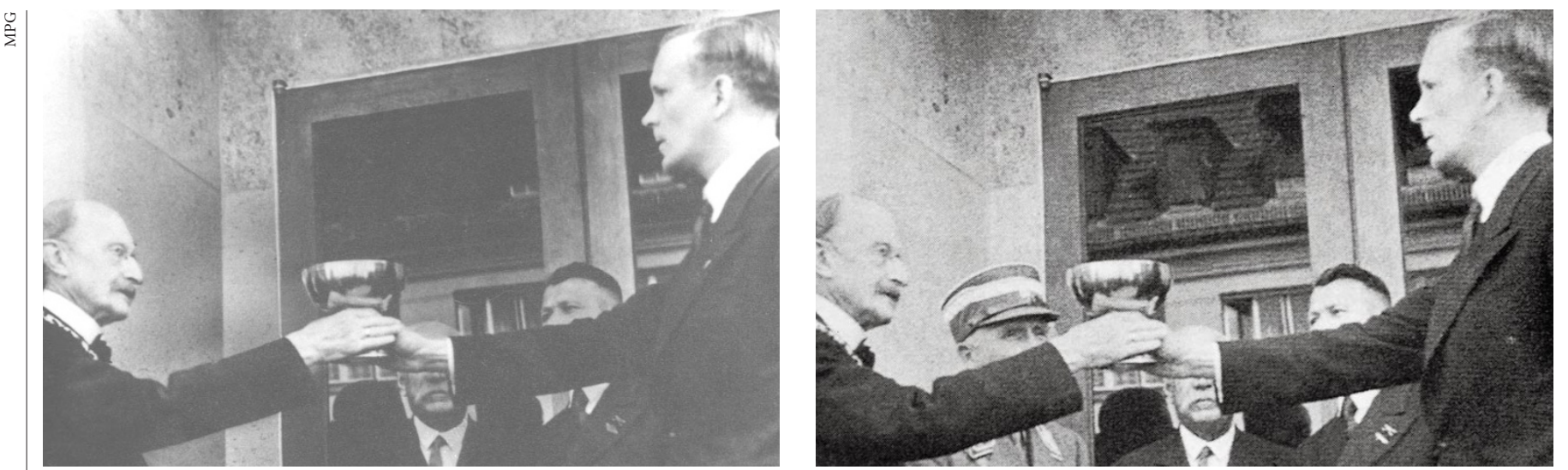

Spot the difference: Werner Köster, handing Max Planck a goblet filled with wine from 1911 - the year that Planck won the Nobel prize. The ceremony took place at the Institute for Metallurgy in Stuttgart in 1934. The Nazi officer was removed in the version printed in 1949 in the Festschrift celebrating the institute's twenty-fifth anniversary (left). The original reappeared in a 1989 paper. The discrepancy was spotted by historian Helmut Maier.

uncover one scandal after another, though this will, of course, happen in time". Although keen "to make clear that atrocious experiments were carried out", she adds that "it is important to go further and focus on scientific practice itself and the role of science in shaping policies".

The research programme aims to investigate the role of Kaiser Wilhelm scientists and research institutes in supporting Nazi policy, and the extent to which they took advantage of opportunities that arose as a result of this policy to advance their careers.

The programme also seeks to identify the role of scientists such as the Vordenker der Vernichtung (planners of extermination) in conceiving and developing racial policies, as

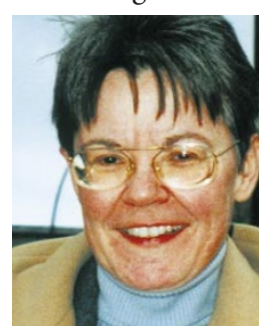

Kaufmann: peering into the 'dark time'. well as in military research and Ostforschung - research in the conquered eastern territories, particularly agricultural and materials research, intended to support Nazi policies of selfsufficiency.

At the specific request of Markl, the historians are also investigating the degree to which scientists of the postwar MPS attempted to call back - or compensate - the 70 or so mostly Jewish KWS scientists who had been thrown out of their institutes during the Nazi period and forced to emigrate.

Although the MPS senate formally recognized such scientists as "External Scientific Members" in 1948, Markl says he would like to know "how intensively and systematically" the society tried to make amends or involve them in the reconstruction of science after the war.

Until the 1980s, says Kaufmann, the dominant view of the role of scientists in the Third Reich - propagated partly by the scientists themselves - was that they had either concentrated on their research and kept out of politics, or been forced to do research sup- porting Nazi policies to ensure their own survival. Many argued that the latter was not real science, but 'pseudoscience', says Kaufmann.

Recent archival research, and a new willingness to accept that even 'good' science, rigorously conducted on dispassionate and rational criteria, can be morally questionable, have turned this view around, she says. But Kaufmann notes that, even now, many scientists are reluctant to accept that 'good' science was carried out by respected researchers deliberately supporting Nazi policy, and her work sometimes "makes her unpopular" in the scientific community.

\section{From lab to concentration camp}

One example of such rigorous, if controversial, research was that carried out by Ernst Rüdin. The director of the Kaiser Wilhelm Institute for Psychiatry in Munich, Rüdin was widely recognized for his theories, published in 1916, on the heritability of schizophrenia. Recent research has shown that he was also instrumental in drawing up the Nazi law on compulsory sterilization of mentally handicapped people, insisting that strict scientific criteria be developed to select those who should be sterilized.

During a six-month study period as guest scientist of Kaufmann's programme, Volker Roelcke, professor of medical history at the University of Lübeck, discovered that Rüdin provided both intellectual and financial support for experiments by Julius Deussen, a young psychiatrist at the University of Heidelberg, designed to develop such criteria.

Deussen used advanced behavioural and biochemical methods to study mentally handicapped children. The children were then killed, their brains examined and the results compared with clinical data. "This was not pseudoscience, but real science, using up-to-the-minute methods," says Roelcke. The aim was to determine correlations between different data sets to aid the

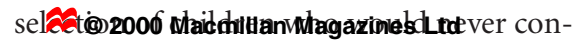
tribute usefully to society.
Such stories are not the whole history of science in the Third Reich. Much of Kaufmann's programme addresses how scientists used the opportunities resulting from Nazi policies and the war. Susanne Heim, for example, a member of Kaufmann's team, is investigating several such cases, including that of Hans Stubbe, who became a top plant geneticist in East Germany after the war.

Stubbe, says Heim, appears to have been an opportunist, ruthlessly following any path that would help his research and career. His strong international connections meant that the Institute for Plant Genetics and Research into Cultivated Plants in Gatersleben near Halle, of which he was director, became well known in the West.

The institute was particularly highly regarded because it housed the second largest plant collection in Europe, after Leningrad. Stubbe made the most of the opportunities created by the Nazi policy of 'autarky', or self-sufficiency in food supplies. During the war, for example, he went to the Balkans immediately after their conquest, accompanying the Italian and German armies, to collect wild plants.

As the first director of the Kaiser Wilhelm Institute for Cultivated Plant Research near Vienna, which opened in 1943, he also collaborated with the SS to plunder valuable Russian collections of wild and cultivated plants after Russia was invaded. He even tried to join the SS himself to make his work easier, but as a known left-winger, his application was turned down.

"Stubbe was not an out-and-out Nazi," says Heim. "It is important to study the relationship that successful KWS scientists had to politics. Scientists like Stubbe were very much aware of the political context in which they worked, even though many scientists like to believe they "just got on with their basic research." Alison Abbott 